\title{
International Capital Mobility and Crowding-out in the U.S. Economy: Imperfect Integration of Financial Markets or of Goods Markets?
}

\author{
Jeffrey A. Frankel
}

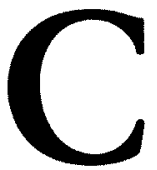

onventional wisdom in the field of international finance holds that the U.S. economy has become so open financially as to be characterized by perfect capital mobility: A highly elastic supply of foreign capital prevents the domestic rate of return from rising significantly above the world rate of return. This view has been challenged recently by the observation that investment rates are highly correlated with national saving rates, and the claim by Feldstein and Horioka that this correlation is evidence of relatively low capital mobility. The experience of the United States in the 1980 s seems to confirm this challenge. The decline in U.S. national saving has been partly offset by a capital inflow from abroad, but the effect has not been large enough to prevent U.S. real interest rates from rising and to an extent crowding out domestic investment.

The premise of this chapter is that the Feldstein-Horioka finding regarding crowding-out in an open economy is strong enough to survive the econometric critiques that have been leveled against it, but that it need have nothing to do with the degree of capital mobility in the sense of the openness of financial markets and the equalization of international interest rates expressed in a common currency. It is real interest rates that matter for questions of crowding-out, and real interest parity requires not just that nominal interest rates be equalized and expressed in a common currency, but also that purchasing power parity hold. It is well known that purchasing power parity does not in fact hold. Currently, for example, the dollar is expected to depreciate in real terms. Thus real interest rate parity fails and crowding-out takes place because of imperfect integration of goods markets, not imperfect integration of financial markets.

I would like to thank Ken Froot, Youkyong Kwon, Tom Walter, and especially Alan MacArthur for their efficient research assistance. I would also like to thank Jim Boughton, Lans Bovenberg, Ken Froot, Frederic Mishkin, Maurice Obstfeld, and Kerry Odell for comments and suggestions. Views expressed here represent the opinions of the author and should not be interpreted as views of the International Monetary Fund. 
The first major section of this chapter presents the issues in the context of crowding-out by the U.S. budget deficit in the 1980s. The second section presents regressions of investment against national saving on U.S. historical data. The third discusses three distinct senses in which the term perfect international capital mobility has been used: (1) closed interest parity, (2) uncovered interest parity, and (3) real interest parity. It also attempts to see how much of the real interest differential can be explained by expected real depreciation. The final section offers conclusions.

\section{International Capital Mobility and U.S. Crowding-out in the 1980 s}

It is a commonplace that the U.S. economy has over its history become increasingly integrated into world goods markets and financial markets. As regards goods markets, imports and exports (averaged) as a share of GNP rose gradually at an annual trend rate of .096 percent a year from 1929 to 1984 , reaching 9.1 percent of GNP in the 1980s. ${ }^{1}$ The percentage of the economy consisting of goods and services that are potentially tradable internationally, as opposed to actually traded, is of course considerably higher. International competition now reaches almost everywhere, beyond U.S. manufacturing into agriculture and services. Long-run trends toward lower transportation costs, lower tariffs, and an increasingly integrated world culture have all played their parts.

U.S. financial markets are considered to be even more closely integrated with the rest of the world than are goods markets. Here the development of the Eurocurrency market, the removal of capital controls when the Bretton Woods system ended, and the continued technological progress in telecommunications and innovation in the banking system worldwide have all been important. Indeed the assumption of perfect capital mobility has for twenty years now been standard in models of floating exchange rates among the United States and most other major industrialized countries, despite some of the surprisingly strong conclusions that typically follow from it.

One strong conclusion that is thought to follow from perfect capital mobility is that a fiscal expansion has no effects-neither a negative effect on investment nor a positive effect on aggregate output. The absence of an effect on investment arises because a potentially infinite capital inflow prevents the domestic interest rate from rising above the world interest rate, so that none of the crowding out of investment that is usual in closed economy models occurs. The absence of an effect on aggregate output arises because the currency appreciates and worsens the trade balance by precisely enough to offset the gain in domestic demand. One can see from a money market equilibrium condition that if the interest rate does not change, because it is tied to the 
foreign interest rate, and the real money supply does not change, then real income cannot change. ${ }^{2}$

The question of fiscal crowding-out has become especially topical in the 1980s because of the large structural fiscal deficits run by the U.S. federal government. According to some theories an increase in government dissaving should be precisely offset by an increase in private saving, by people putting aside money to help their children pay future taxes, so that there is no effect on total national saving. (National saving is defined as whatever private saving is left over after the government budget deficit has been subtracted out.) Whatever one thinks of the theoretical merits of the argument, the results of the current experiment seem clear. The increase in federal dissaving from the 1970 s to the 1980 s has not been matched by a rise in private saving. The rate of total national saving has fallen, from 16.1 percent of GNP on average from 1973 to 1980 to 14.5 percent from 1981 to $1984 .^{3}$

As a matter of accounting identity, this fall in national saving must equal the rise in net capital inflow from abroad plus the fall in domestic investment. The question of interest is how the change is divided up between the two. There has in fact been a large net capital inflow, the counterpart of the record current account deficits, but it has not been large enough to prevent the investment rate from falling, from 16.1 percent of GNP from 1973 to 1980 to 15.4 percent from 1981 to $1984 .^{4}$

More visibly, the capital inflow has not been large enough to prevent U.S. real interest rates from rising sharply, even vis-à-vis foreign real interest rates. There are of course different ways of measuring the real interest rate. For questions of saving and investment, the long-term nominal interest rate is to be preferred over the short-term rate. But measuring inflation expectations is more problematic in the long term than in the short term. Table 2-1 reports measures of long-term real interest rates using four measures of expected inflation that are available for both the United States and major trading partners: A three-year lag on past inflation (with weights $.5, .3$, and .2), forecasts by Data Resources, International (DRI), forecasts by the OECD, and a survey by American Express of opinions among 250 to 300 central bankers, private bankers, corporate treasurers and finance directors, and economists. By any of the four measures there was a clear increase in the U.S. real interest rate after 1980 , both absolutely and relative to a weighted average of trading partners. The long-term real interest differential stood at about 3 percent in the first part of 1985 , as compared to -2 percent five years earlier.

For those outside the field of international economics, the novel feature of the 1980s is the magnitude of the U.S. capital inflow and of its counterpart, the notorious record trade deficits. The unfavorable effect of the latter on U.S. export- and import-competing sectors has of course received a great deal of attention; and the favorable effect of the former, keeping interest rates 
Table 2-1

Interest Rate Differentials between U.S. and Foreign Assets, and Other Measures of the Expected Rate of Dollar Depreciation, 1976-85 (percent per annum)

\begin{tabular}{|c|c|c|c|c|c|c|}
\hline & & $1976-78$ & $1979-80$ & $1981-82$ & $1983-84$ & 1985 \\
\hline \multicolumn{7}{|c|}{ Expected nominal rate of depreciation } \\
\hline 1.1 & One-year interest differential ${ }^{a}$ & -0.48 & 2.29 & 3.00 & 1.73 & 1.15 \\
\hline 1.2 & One-year forward discount & 0.18 & 2.57 & 3.34 & 1.85 & 1.32 \\
\hline 1.3 & Ten-year interest differential & -0.50 & 0.56 & 1.91 & 2.47 & 2.92 \\
\hline 1.4 & Economist survey $^{\mathrm{b}}$ & NA & NA & 8.57 & 8.60 & 7.12 \\
\hline 1.5 & American Express survey ${ }^{c}$ & 0.64 & NA & 6.67 & 6.99 & NA \\
\hline \multicolumn{7}{|c|}{ Expected inflation rate differential } \\
\hline 2.1 & One-year lag & -1.01 & 3.54 & 0.88 & -0.35 & 0.06 \\
\hline 2.2 & Three-year distributed lag & -1.96 & 2.70 & 1.89 & -0.18 & -0.16 \\
\hline 2.3 & DRI three-year forecast ${ }^{d}$ & NA & 2.20 & 0.96 & 0.23 & 0.15 \\
\hline 2.4 & OECD two-year forecast ${ }^{e}$ & 1.42 & 2.24 & 0.62 & 0.61 & -0.20 \\
\hline 2.5 & American Express survey $f$ & -0.75 & NA & 4.11 & 2.68 & NA \\
\hline
\end{tabular}

Expected real rate of depreciation

1.1-2.1 One-year real interest differential

1.3-2.2 Ten-year with distributed lag

\begin{tabular}{rrrrr}
0.53 & -1.24 & 2.12 & 2.09 & 1.08 \\
1.47 & -2.15 & 0.02 & 2.64 & 3.08 \\
& & & & \\
NA & -1.64 & 0.95 & 2.24 & 2.77 \\
& & & & \\
-1.92 & -1.68 & 1.29 & 1.86 & 3.12 \\
1.39 & NA & 2.56 & 4.31 & NA \\
NA & 1.10 & 1.79 & 1.65 & 1.80 \\
NA & 1.60 & 3.99 & 2.60 & 3.09 \\
\hline
\end{tabular}

\section{3-2.3 Ten-year with DRI} forecast

1.3-2.4 Ten-year with OECD forecast

1.5-2.5 American Express survey Dividend/price ratiog Earnings/price ratiog

Sources unless otherwise specified: International Monetary Fund International Financial Statistics and DRI FACS financial data base, Data Resources, International.

Note: The foreign variables are GNP-weighted averages of the United Kingdom, France, West Germany, and Japan, unless otherwise specified.

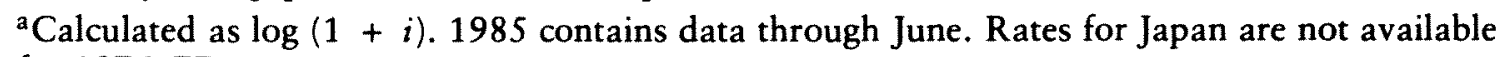
for 1976-77.

bAvailable at 24 survey dates. Source: Economist Financial Report (various issues).

${ }^{c}$ Available at 11 survey dates. Source: American Express Bank Review (various issues).

dAverages of same 24 dates as in footnote ${ }^{b}$. Source: DRI forecasts.

e 1976-78 data covers only December 1978. 1985 data covers only June 1985. Source: OECD Economic Outlook.

${ }^{f}$ Available at same 11 survey dates as in footnote ${ }^{c}$ for the United States, United Kingdom, and West Germany. Available at only four survey dates (1976-78) for France.

gEnd-of-quarter averages. 1979-80 includes data only for 1980. 1985 data is for end of first quarter. Foreign ratios represent the aggregate of Europe, Australia, and the Far East. Source: Capital International Perspective, Geneva. 
from rising as much as they otherwise would, has received some attention as well. But for those inside the field the interesting question is rather: If capital mobility is as perfect as economists have been assuming, why has there been any rise in the real interest differential; why has the increase in the net capital inflow not been large enough to prevent any crowding out of investment; and why has the increase in the trade deficit not been large enough to counteract the expansionary effects of the fiscal policy so as not to leave any net effect on national income?

\section{Correlations of Saving and Investment}

\section{The Feldstein-Horioka Methodology}

Even before the current episode, Feldstein and Horioka (1980) initiated a controversy on the subject of the implications of perfect capital mobility. They ran cross-sectional regressions of investment against national saving, found coefficients much closer to one than to zero, and interpreted the results as evidence that capital mobility is in fact far less than perfect. The argument was that if a country faced an infinitely elastic foreign supply of capital that prevented the domestic rate of return from rising above the foreign rate, then random variation in propensities to save or in government deficits should be fully offset by international capital flows, and there would be no reason for them to have any effect on investment rates.

The Feldstein-Horioka work has been subjected to a barrage of critiques. Virtually all of them are econometric in nature. Little of the commentary has tried to define better than did Feldstein and Horioka what precisely is the hypothesis that one is seeking to test, or how it relates conceptually to more conventional definitions of capital mobility based on rates of return. Doing so is one of the major aims of this chapter. ${ }^{5}$

But first I will address some of the econometric critiques of the FeldsteinHorioka regressions. Consider the national saving identity with each of its components specified as functions of the rate of return $r$ :

$$
I(r)-N S(r, \bar{G})=K A\left(r-r^{*}\right)
$$

where $I$ is investment, $N S$ is national saving, $K A$ is the net capital inflow from abroad, and $\bar{G}$ is government expenditure, or any other determinant of NS thought to be exogenous. Then (assuming also that $r^{*}$, the foreign rate of return, is exogenous),

$$
\frac{d I}{d \bar{G}}=I_{r} \frac{d r}{d \bar{G}}=\frac{N S_{\bar{G}}}{1+\left(K A_{r}+N S_{r}\right) /\left(-I_{r}\right)}
$$


This derivative is in general negative, assuming $N S_{\bar{G}}$ is. But it is zero if $K A_{r}=$ $\infty$, and is equal to the closed economy crowding-out effect if $K A_{r}=0$.

There are three basic econometric difficulties with regressions of investment against national saving. The first, which arises only in time series studies, is the strongly procyclical nature of both saving and investment, even when expressed as shares of GNP (as they always are in these studies). If an exogenous boom causes the saving rate and investment rate both to rise, I do not want to attribute it to low capital mobility. For this reason, Feldstein and Horioka restricted their analysis to cross-sectional data, as did most who followed in their footsteps. ${ }^{6}$ The second econometric difficulty is the "largecountry problem": The United States and other major countries cannot take the world rate of return $r^{*}$ as exogenous. Even if perfect capital mobility equates the domestic interest rate to the world interest rate, a fall in domestic saving will reduce domestic investment to the extent that it drives up the world interest rate. ${ }^{7}$

The third econometric difficulty is the general one of endogenicity of the independent variable. The error term in the regression equation consists of all factors determining investment, other than the rate of return (and GNP). If they happen to be uncorrelated with the independent variable, there is no problem. But this is unlikely, especially in light of the identity linking saving and investment.

Probably the most popular criticism of the Feldstein-Horioka regressions is the "policy reaction" argument: Governments react to current account imbalances so as to reduce them. For example, if the government reacts to a trade deficit induced by a random increase in investment, by cutting government expenditure or raising taxes, then national saving and investment will be correlated for reasons having nothing to do with capital mobility ${ }^{8}$ If endogeneity of national saving were the only problem, economists could invert the equation and regress national saving against investment; the hypothesis that capital is in infinitely elastic supply at a given rate of return would still imply a zero coefficient. This test would be equivalent (given the national savings identity) to regressing the current account against investment; the null hypothesis would in that case be a unit coefficient, implying that any exogenous changes in investment are fully financed by borrowing from abroad. This in fact is the equation run by Sachs $(1981,1983)$. But arguments as to why saving should be endogenous apply also to investment. Clearly the right answer is that national saving, investment, and the current account are all endogenous, and no ordinary least-squares (OLS) regression is appropriate.

If the motivation is to see whether changes in private saving or the government budget would crowd out investment in an open economy, then economists should indeed think of the former as a right-hand side variable and the latter as the left. But the technique that is required is instrumental 
variables. Total government expenditure is probably not a good enough instrument because under the policy-reaction argument, it is endogenous. Two better candidates are military expenditure and the age composition of the population. The former is most immediately a determinant of the government budget deficit and the latter of private saving. It is possible to think of ways that either could be endogenous; it is conceivable that military expenditure could be cut back in response to trade deficits and that the age composition of the population could respond to the growth rate. It is also possible to think of ways that either could affect investment through routes other than saving and the rate of return. But these two variables seem to meet the criteria for instruments at least as well as most alleged instrumental variables in macroeconomics. ${ }^{9}$

\section{U.S. Saving and Investment Time Series}

This section reports Feldstein-Horioka tests on U.S. data. Econometric "fix-ups" for each of the three kinds of problems are attempted. But no claim is made that the results are good tests of the degree of capital mobility. Indeed, it is argued in subsequent sections that they are not. In this chapter in a sense I follow in a tradition of other economists who have criticized Feldstein and Horioka and then found the temptation irresistible to do a few tests of their own on the grounds that the high correlation of savings and investment is an interesting empirical regularity. ${ }^{10}$

If one is concerned with the worldwide degree of capital mobility or crowding out, then cross-sectional studies of the sort performed by Feldstein and Horioka (1980), Penati and Dooley (1984), and others are appropriate. However, if one seeks to isolate such parameters for the United States in particular, and if one wishes to see how they have evolved over time, then time series regression is necessary. I ran instrumental variables regressions of investment against national saving for the United States from 1870 to 1979. I use decade averages of saving and investment rates, hoping to remove the cyclical variation. The data are graphed in figure $2-1 .{ }^{11}$ One can see that in the 1890 s, U.S. investment fell below national saving, that is, the country began to run current account surpluses, lending abroad in particularly large amounts when Europe was dissaving during World War I. One can also see that both saving and investment fell drastically in the Depression, never fully to return to earlier levels.

Table 2-2 reports the results of the instrumental variables regressions. The coefficient estimate is .96 , indicating a very high degree of crowding-out ("low capital mobility"). Despite the very small number of observations (eleven) the standard error is relatively small. Even when corrected for the (marginal) presence of serial correlation, the estimate is high (.91) and one can easily reject the hypothesis of zero crowding-out ("perfect capital mobil- 
40 - How Open Is the U.S. Economy?

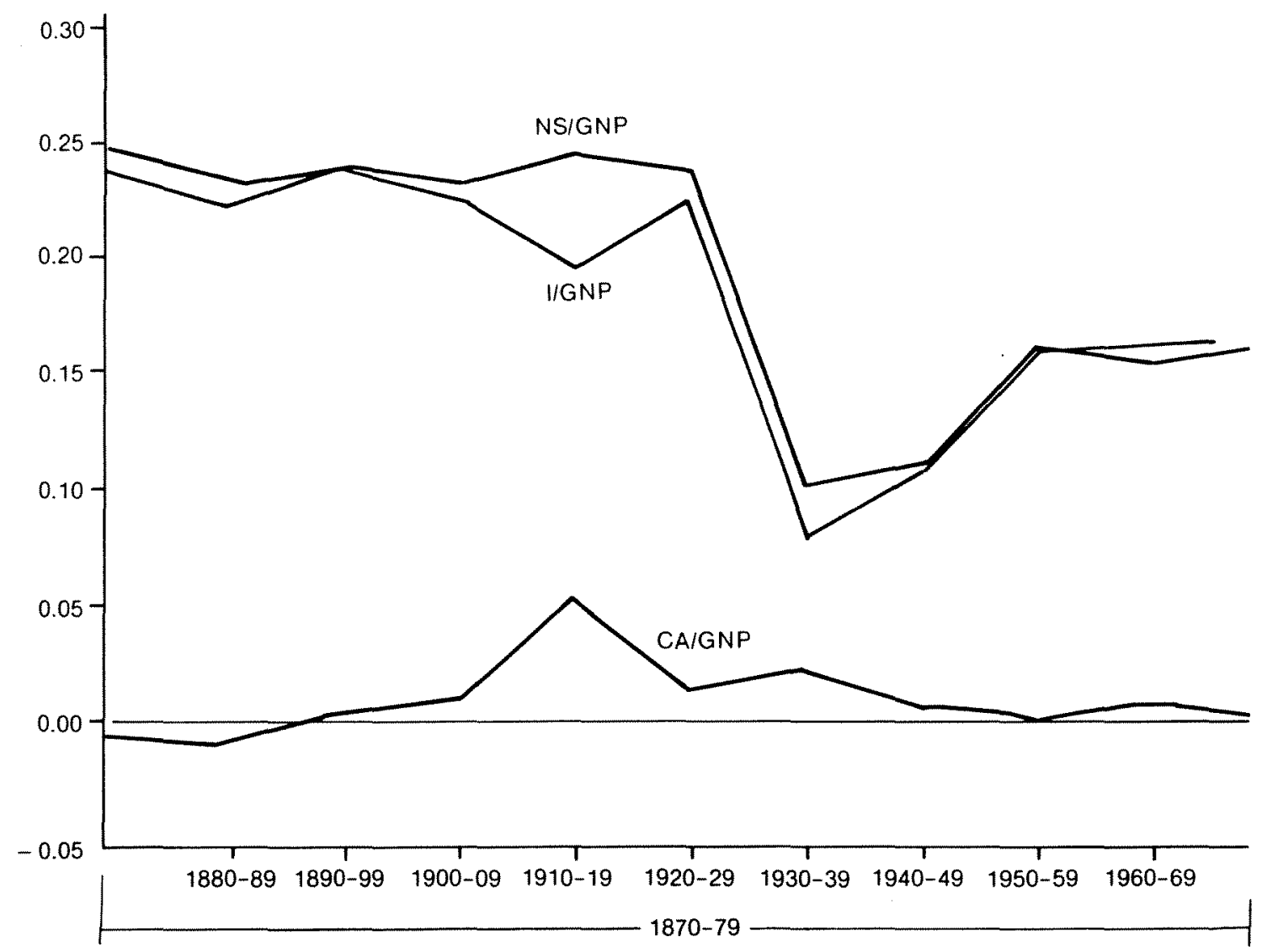

Sources: Roger Ransom and Richard Sutch, "Domestic Saving as an Active Constraint on Capital Formation in the American Economy, 1839-1928: A Provisional Theory." University of California Project on the History of Saving, Working Paper no. 1. University of CaliforniaBerkeley, 1983, Tables 4 and E1; and U.S. Department of Commerce, Historical Statistics of the U.S.

\section{Figure 2-1. U.S. National Saving (Private Saving plus Government Budget Surplus) (NS), Investment (I), and Current Account (CA) as Shares of GNP, 1870-1979}

ity"), though one cannot reject the opposite extreme. To try to see whether the relationship has changed over time, I added a coefficient trend term. Its sign is positive, pointing to an increasing degree of crowding out, but it is not statistically significant, as one would expect from the small number of observations. ${ }^{12}$

A more recent data set would seem more promising for two reasons. First, yearly data are available. Second, it is widely believed that the postwar trend toward increased integration of the economies of the United States and other countries, both with respect to financial markets and goods markets, merely reversed sharp movements in the opposite direction that took place in the interwar period. Thus one looks for a trend beginning in the 1930s at the earliest. 
Table 2-2

Instrumental Variables Regression of U.S. Investment against National Saving, Decades 1870-1979

\begin{tabular}{|c|c|c|c|c|c|c|}
\hline & Constant & Coefficient & $\begin{array}{l}\text { Time Trend } \\
\text { in } \\
\text { Coefficients }\end{array}$ & $\begin{array}{c}\text { Durbin-Watson } \\
\text { Statistic }\end{array}$ & $\begin{array}{l}\text { Autoregressive } \\
\text { Parameter }\end{array}$ & $R^{2}$ \\
\hline 1. & $\begin{array}{l}.000 \\
(.028)\end{array}$ & $\begin{array}{l}.957 \\
(.144)\end{array}$ & & 1.5 & & .91 \\
\hline 2. & $\begin{array}{l}.007 \\
(.914)\end{array}$ & $\begin{array}{l}.914 \\
(.238)\end{array}$ & & & $\begin{array}{l}.20 \\
(.37)\end{array}$ & .91 \\
\hline 3. & $\begin{array}{r}-.025 \\
(.083)\end{array}$ & $\begin{array}{l}1.035 \\
(.203)\end{array}$ & $\begin{array}{l}.010 \\
(.030)\end{array}$ & 1.2 & & .89 \\
\hline
\end{tabular}

Notes: Standard errors are reported in parentheses.

Dependent variable: productive capital formation/GNP

Independent variable: (gross private saving plus increase in government debt)/GNP

Source: Roger Ransom and Richard Sutch. "Domestic Saving as an Active Constraint on Capital Formation in the American Economy, 1839-1928: A Provisional Theory." University of California Project on the History of Saving, Working paper no. 1. University of California-Berkeley, 1983, tables 4 and E1.

Instrumental variables: (Department of Defense outlays/GNP) and (population 65 years of age and over/population over age 20).

Sources: Historical Statistics of the U.S., Series Y 458-460 and Series A 119 and 133, respectively, Department of Commerce.

Tables 2-3 and 2-4 repeat the regressions for yearly U.S. data in the period 1930-84. In this case, with the greater number of observations, one can reject both extremes of zero and one, even when making the necessary correction for serial correlation. One can also identify a statistically significant time trend of .01 per year in the coefficient. It implies that the degree of crowding out rises over time, from an estimated coefficient of .19 in 1930 (insignificantly different from zero) to an estimated coefficient of .74 in 1984 (insignificantly different from unity). An alternative way to see how the coefficient changes over time is to split the sample. I chose as the breaking point 1958, the year when the European countries restored convertibility of their currencies. The two coefficients are very similar, .75 in the first half of the sample and .78 in the second. In both cases one can easily reject a zero coefficient, but in the $1959-84$ period one is unable to reject a coefficient of unity.

One would expect that the foregoing coefficient estimates would be biased upward by the cyclical endogeneity problem, because they are not based on longer-term averages. Table $2-4$ reports regressions using yearly saving and investment rates that have been cyclically adjusted. The cyclical adjustment of each is accomplished by first regressing it on the GNP gap, defined as the percentage deviation from the Bureau of Economic Analysis's 
42 - How Open Is the U.S. Economy?

Table 2-3

Regressions of Investment against National Saving (Both as Shares of GNP), Yearly Data, 1930-84

\begin{tabular}{lccccc}
\hline & & \multicolumn{3}{c}{ Time Trend } \\
in \\
& Constant & Coefficient & Coefficient & $\begin{array}{c}\text { Autoregressive } \\
\text { Parameter }\end{array}$ & $R^{2}$ \\
\hline $1930-84$ & .068 & $.484^{*}$ & & .80 & .88 \\
& $(.017)$ & $(.096)$ & & $(.09)$ & .86 \\
$1930-84$ & .050 & $.176^{*}$ & $.013^{*}$ & .67 & .96 \\
$1930-58$ & $(.025)$ & $(.188)$ & $(.003)$ & .68 & .93 \\
$1959-84$ & .021 & $.752^{*}$ & & $(.14)$ & .70 \\
& $(.019)$ & $(.104)$ & & .55 & $(.25)$ \\
\hline
\end{tabular}

Sources: For gross saving and gross private domestic investment, 1985 Economic Report of the President, table B-25. For cyclical adjustment, "Middle Income Expansion Trend," Survey of Current Business (U.S. Dept. of Commerce, December 1983). For instrumental variables, Historical Statistics of the U.S., Series Y 458-460 and Series A 119 and 133, Department of Commerce.

Notes: Standard errors are reported in parentheses.

Instrumental variables: Military expenditure/GNP ratio and over-65 population ratio.

* Statistically significant at 95 percent level.

Table 2-4

Regressions of Investment against National Saving (Both as Cyclically Adjusted Shares of GNP), Yearly Data, 1955-84

\begin{tabular}{lcccccc}
\hline & & & Time Trend & & \\
in & & Durbin-Watson & Autoregressive \\
Parameter & $R^{2}$ \\
\hline $1955-84$ & Constant & Coefficient & Coefficient & Statistic & & .41 \\
$1956-84$ & & $.699^{*}$ & & .86 & & \\
& & $(.190)$ & & & .60 & .52 \\
$1956-84$ & .003 & $.803^{*}$ & & & $(.22)$ & \\
& $(.006)$ & $(.429)$ & & .77 & .46 \\
$1955-73$ & -.003 & $.761^{*}$ & $(.029)$ & & $(.26)$ & \\
& $(.002)$ & $(.189)$ & & .27 & $(.25)$ & .69 \\
$1975-84$ & .042 & .181 & & & .93 & .21 \\
& $(.232)$ & $(.645)$ & & & & \\
\hline
\end{tabular}

Sources: For gross saving and gross private domestic investment, 1985 Economic Report of the President, table B-25. For cyclical adjustment, "Middle Income Expansion Trend," Survey of Current Business (U.S. Dept. of Commerce, December 1983). For instrumental variables, Historical Statistics of the U.S., Series Y 458-460 and Series A 119 and 133, Department of Commerce.

Notes: Standard errors are reported in parentheses.

Instrumental variables: Military expenditure/GNP ratio and over-65 population ratio.

"Statistically significant at 95 percent level. 


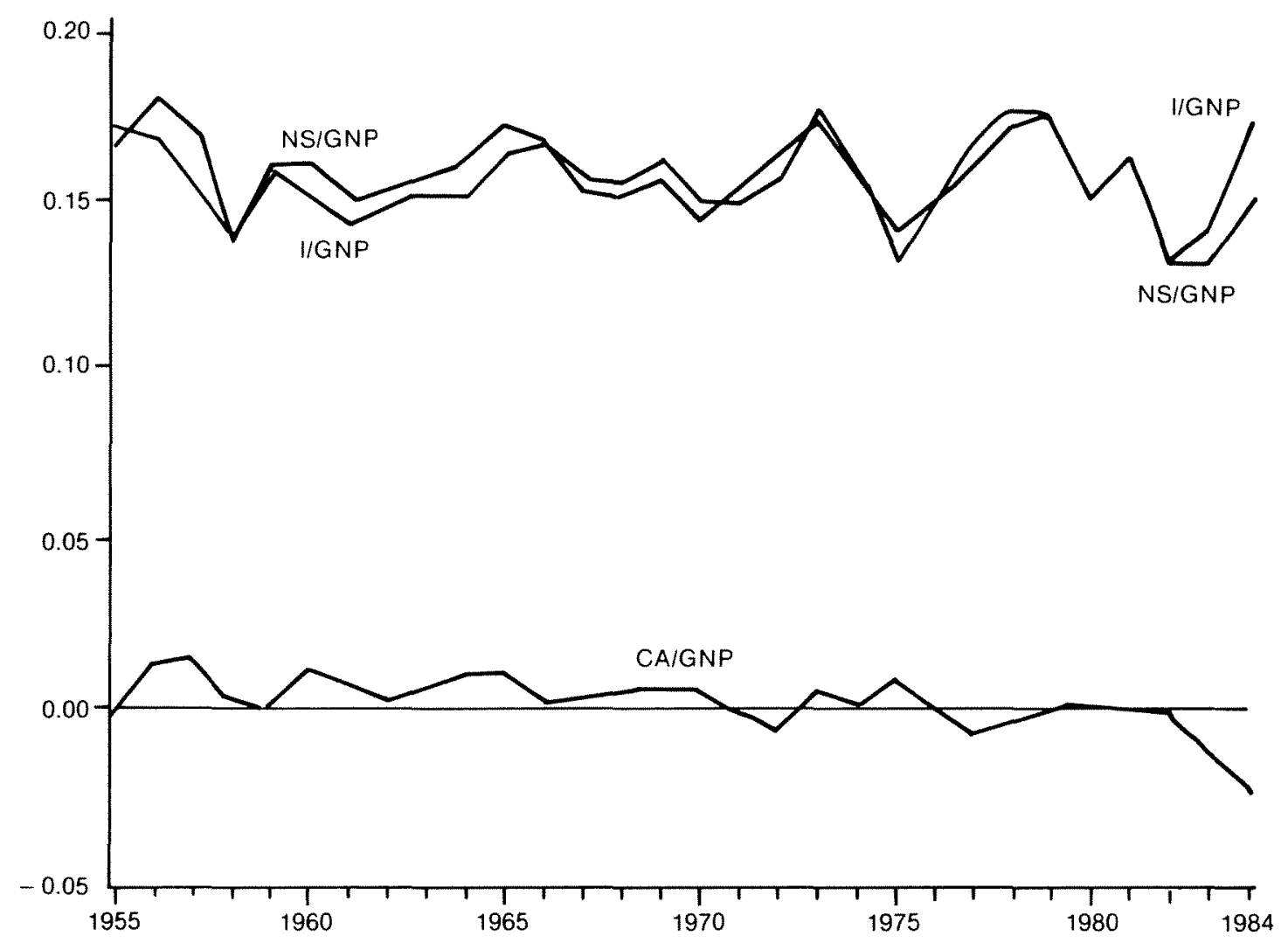

Source: 1985 Economic Report of the President.

Figure 2-2. U.S. National Saving (NS), Investment (I), and Current Account (CA) as Shares of GNP, 1955-84

"middle expansion trend" of GNP and taking the residuals. The saving and investment rates are graphed in figures 2-2 and 2-3 for the period 1955-84. They are more stable than earlier in U.S. history. ${ }^{13}$ Nevertheless there is enough variation to see that the two series do move together, even after the cyclical variation has been taken out (figure $2-3$ ). The cyclically adjusted investment and saving rates show a regression coefficient of .81 . This is similar to the estimate for the much longer 1870-1979 period (.91) in that one can easily reject zero but cannot reject unity. Attempts to find a postwar trend in the coefficient or a break in the data when capital controls were removed in 1974 suggest that the coefficient has been moving closer to one-that is, that the degree of crowding out has increased (or the degree of capital mobility has fallen). But the standard errors are too large, probably because the number of observations and the variation in the data are too small, for the shift to be statistically significant.

The failure to reject complete crowding-out is the same result found by Obstfeld (1985, pp. 39-43) on quarterly U.S. data. The failure to find a drop in the coefficient even in the 1970s is the same result found by Feldstein 
44 - How Open Is the U.S. Economy?

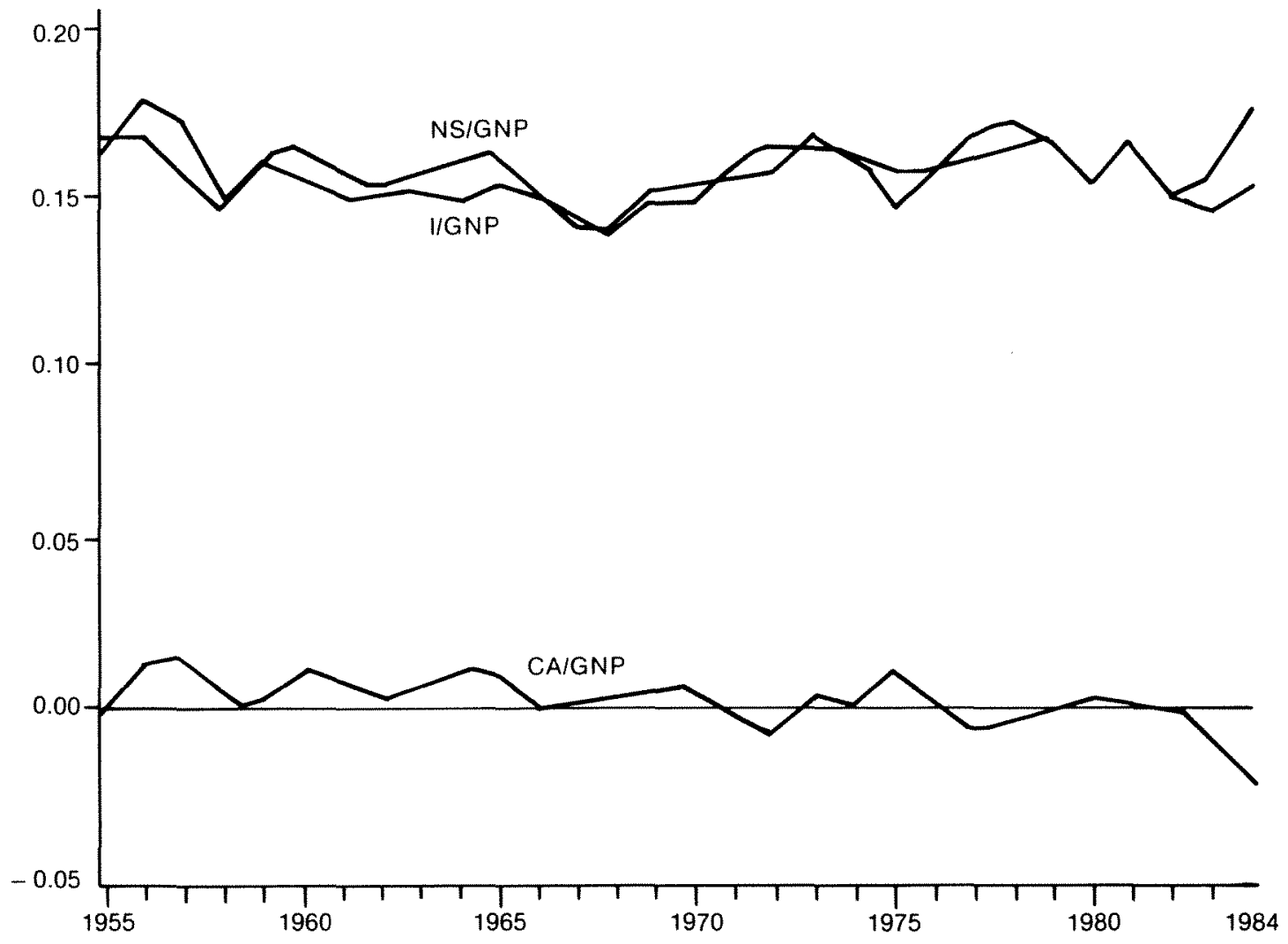

Source: 1985 Economic Report of the President and U.S. Department of Commerce, Survey of Current Business.

Figure 2-3. U.S. National Saving (NS), Investment (I), and Current Account (CA) as Cyclically Adjusted Shares of GNP, 1955-84

(1983) and Penati and Dooley (1984, pp. 8-10), and interpreted by them as contradicting the popular impression of an increase in the degree of capital mobility among OECD countries.

Obstfeld (1985) attributes the continued high magnitude of the U.S. coefficient in the recent period to the large-country problem. It remains even after the use of instrumental variables and cyclically adjusted numbers. The next step is to relate the differential between the U.S. investment rate and the rest of the world's investment rate to the differential in national saving rates. Under the null hypothesis, an exogenous fall in the U.S. national saving rate may drive up the world real interest rate and crowd out investment, but there is no reason for the crowding-out to be reflected in U.S. investment any more than in the rest-of-the-world investment. Such differential saving rates and investment rates are calculated in table 2-5. The close correspondence between U.S. saving and investment remains: The coefficient in a regression is .740, and is highly significant despite the small number of observations. ${ }^{14}$ 


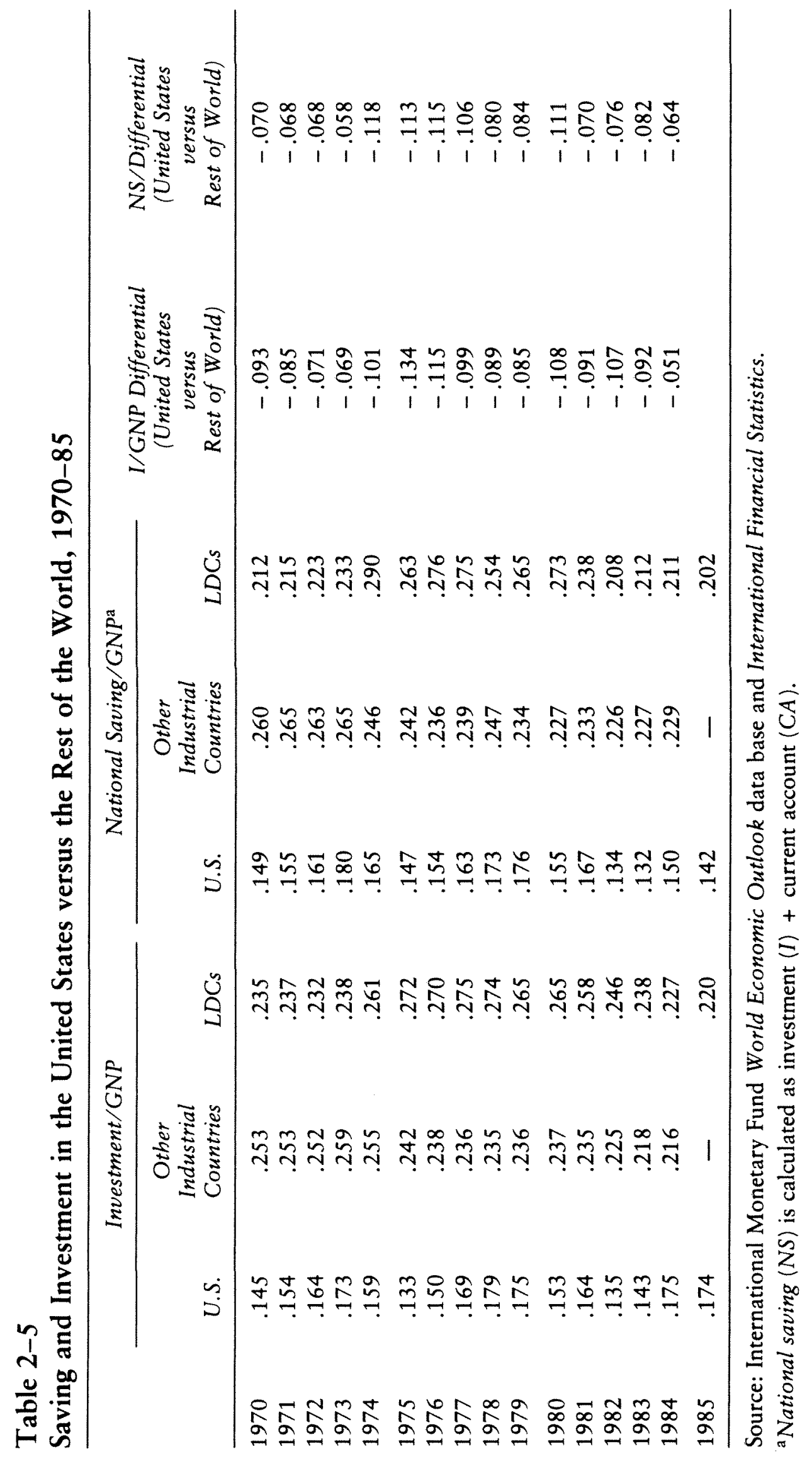




\section{What Is the Meaning of Capital Mobility?}

The apparent finding of a relatively low degree of capital mobility in the saving-investment studies, from Feldstein-Horioka to the results just reported, seems puzzling-even startling-to one accustomed to thinking of capital as perfectly mobile internationally. This is one reason for the succession of econometric critiques of their paper. The instrumental variable results are a partial answer to the critiques (more or less convincing according to whether the military expenditure and age structure variables are considered more or less valid instruments). But even if one believes that problems of econometric endogeneity remain, as is likely, it seems intuitively clear that a degree of domestic crowding out fundamentally exists, and that even if truly exogenous changes in national saving could be isolated, they would not be found to be offset one-for-one by net capital inflow.

Most readers of the Feldstein-Horioka paper and subsequent literature have from the start been vaguely bothered by the connection, or lack of it, between the two authors' use of the phrase perfect capital mobility and the use of the phrase that existed previously in the field of international finance. Feldstein and Horioka themselves take pains to say that they are talking about long-term, as distinct from short-term, capital mobility. One problem with this type of argument is that if short-term assets and long-term assets are relatively close substitutes within each country, then international arbitrage of short-term rates of returns would be all that is required. It may be that short-term treasury bills are not in fact close substitutes for long-term bonds, equities, or real capital within a given country; but if so, this is not the fault of international capital mobility.

Penati and Dooley, who generally confirm the findings of Feldstein and Horioka, come closer to describing the connection with traditional notions of capital mobility by emphasizing the distinction between gross flows and net flows:

It is not necessarily true that a large volume of two-way trade in financial assets is associated with net trade in financial assets. But it is the net trade, together with the associated net trade in goods and services, that allows domestic investment to diverge from domestic savings (p. 7).

This is clearly right. But the question that remains to be answered is: If there are no barriers to the gross acquisition of assets across national boundaries, how can there be barriers to the net acquisition of assets? Is not "gross" capital mobility sufficient to equalize interest rates? And if it is, how is it that changes in national saving seem to crowd out investment in their own country?

I turn now to traditional definitions of international capital mobility, where the operational criteria are stated in terms of differential rates of return 
rather than correlations of saving and investment. Later I will return to the meaning of the correlations.

\section{Three Interest Parity Conditions as Definitions of Capital Mobility}

The term perfect capital mobility is commonly used in three distinct ways. In each case the operational criterion is a version of international interest rate parity.

\section{Closed Interest Parity}

The first definition is the absence of important capital controls, transactions costs, or other barriers separating investors from the assets that they would like to hold. ${ }^{15}$ The operative criterion is that arbitrage equalizes nominal interest rates on assets located in different countries, when any exchange rate risk has been removed. This criterion is most often stated as covered interest parity:

$$
i=i^{*}+f d
$$

where $i$ is the domestic nominal interest rate, $i^{*}$ the foreign nominal interest rate, and $f d$ the forward discount on domestic currency.

For the criterion to be an interesting one, the interest rates should refer to securities that differ in political jurisdiction, not just in currency of denomination. The best-known study of covered interest parity, Frenkel and Levich (1975), found the relationship to hold well for Europound and Eurodollar interest rates on deposits side-by-side in a London bank. Indeed if one were to find significant deviations from covered interest parity with such a data set, one would be less likely to change one's view of the world than to question the reliability of the data set. The interesting criterion instead uses, for example, London interest rates and New York interest rates. The London interest rate can be either a Eurodollar rate $\left(i_{\mathrm{L}}^{\mathbb{S}}\right)$, or a pound rate $\left(i_{\mathrm{L}}^{f}\right)$ covered on the forward exchange market. In the former case, one would test the condition

$$
i_{\mathrm{NY}}^{\S}=i_{\mathrm{L}}^{\S}
$$

which one might call "absolute" or "simple" interest parity. In the latter case one would test the condition

$$
i_{\mathrm{NY}}^{\S}=i_{\mathrm{L}}^{£}+f d
$$

which is "international" (as opposed to "Euromarket") covered interest parity. 
Given that Euromarket covered interest parity holds,

$$
i_{\mathrm{L}}^{\$}=i_{\mathrm{L}}^{£}+f d,
$$

the other two, more interesting, criteria are identical to each other. If one phrase is desired for the two of them interchangeably, it might be "closed interest parity."

Frenkel and Levich $(1975,1977)$ find that, even for the periods 1962-67 and 1973-75, when Euromarket covered interest parity held well, international covered interest parity, using U.S. and U.K. treasury bills, held significantly less well. They attribute the deviations to what Aliber (1973) called political risk: default, taxation, capital controls, or any other sort of risk attaching to the political jurisdiction of a security as opposed to its currency of denomination. Similarly, Dooley and Isard (1980) find imperfect capital mobility for Germany during the period 1970-74; they use Deutsche mark deposits in Frankfurt versus Euromark deposits in Zurich to test what I have just called absolute or simple interest parity, and find large deviations. Like Aliber and Frenkel and Levich, they attribute the deviations to political risk, specifically allocating primary responsibility to the level of controls in place in Germany at the time (essentially the taxation of interest paid to foreign residents) and secondary responsibility to the uncertainty regarding possible future changes in the level of controls. Fase (1976) finds large deviations from closed interest parity, both simple and covered, for the United States, Canada, Germany, and eight other major countries for the Bretton Woods period of 1961-72.

Germany and the United States removed most of their capital controls in 1974. ${ }^{16}$ Using Granger-Sims causality tests on simple interest parity for the dollar (the Eurodollar rate versus the domestic U.S. commercial paper or Treasury bill rate), Hartman (1984) finds a significant strengthening of the link from the 1971-74 period to the 1975-78 period. Boothe et al. (1985, p. 112) find small deviations for the Canadian dollar in the 1975-82 period.

Britain removed its controls in 1979 , so that by the 1980 s six industrialized countries-the United States, Canada, Germany, the United Kingdom, Switzerland, and the Netherlands-were perceived as having essentially open financial markets. France and Italy, on the other hand, maintain serious controls on capital outflow, as is easily demonstrated by the excess of the Eurocurrency interest rates in London over the domestic rates in France and Italy.

Giavazzi and Pagano (1985, pp. 27-28) find that the deviations from covered interest parity are large enough that domestic arbitrageurs would make guaranteed profits if they could get their money into the Euromarket, on 85 percent of the days in the case of France (September 1982-August 1984 , with a mean return of 3.99 percent) and 60 percent of the days in the case of Italy (November 1980-August 1984, with a mean return of 3.51 per- 
cent), and that the deviations rise sharply before a devaluation. ${ }^{17}$ They also look at Germany and the Netherlands and find deviations that are opposite in sign to those of France and Italy, but that are in any case much smaller in magnitude (the mean returns to covered arbitrage are only 0.34 percent for Germany and 0.14 percent for the Netherlands for the period September 1982-August 1984).

Of the seven summit countries, Japan is the one of controversy. In the late 1970s, Japan maintained strict controls on capital inflow in order to resist the large appreciation of its currency that was taking place. Foreigners were prohibited from acquiring most forms of Japanese securities, such as gensaki, a three-month repurchase agreement. In May 1979, in the face of a depreciating yen, the Ministry of Finance removed most of these prohibitions. The controversy arose in 1983, when some American businessmen, alarmed by devastating competition from Japanese exporters, convinced the U.S. Treasury Department that the Japanese government was still using some form of capital market restrictions to keep the value of the yen lower than it would otherwise be. There followed a campaign by the U.S. government to induce the Japanese to adopt a whole list of measures further liberalizing their financial markets. This campaign came to fruition in the May 1984 Yen/ Dollar Agreement between the U.S. Treasury and the Japanese Ministry of Finance.

This episode is a good case study in which to apply the closed interest parity criterion for capital mobility. One can compute the differential between the three-month Euroyen interest rate in London and the gensaki rate in Tokyo, and compare its magnitude before and after the purported liberalization. Between the period January 1975-April 1979 and the period May 1979-November 1983, the mean absolute value of the deviation fell from 2.06 percent to 0.31 percent and the variance fell from 3.29 percent to 0.22 percent. ${ }^{18}$ The statistics in table $2-6$ show that, by the criterion of closed interest parity, Japanese financial markets are now as open internationally as those of the United Kingdom, Germany, and Switzerland.

Table 2-6

Financial Openness for Five Countries: Eurocurrency Three-Month Interest Rate Less Money Market Rate, October 7, 1983-May, 1984

\begin{tabular}{lccccc}
\hline & \multicolumn{3}{c}{ United } & & \\
& Japan & Kingdom & Germany & Switzerland & France \\
\hline Mean & 0.053 & 0.109 & -0.041 & 0.116 & 1.813 \\
Mean absolute value & 0.101 & 0.114 & 0.103 & 0.161 & 1.813 \\
Mean square & 0.015 & 0.017 & 0.020 & 0.036 & 5.071 \\
Variance & 0.013 & 0.005 & 0.018 & 0.023 & 1.783 \\
\hline
\end{tabular}

Source: J. Frankel, The Yen/Dollar Agreement: Liberalizing Japanese Capital Markets (Cambridge, Mass.: MIT Press, December 1984), p. 24. 


\section{Uncovered Interest Parity}

The second definition of perfect capital mobility is the absence of imperfect substitutability, attributable in particular to risk, between domestic and foreign assets. The operative condition here is uncovered, or open, interest parity:

$$
i^{\$}=i^{£}+\Delta s^{e}
$$

where $\Delta s^{e}$ is the expected percentage depreciation of the dollar over the coming period. In other words, investors respond to any differentials in expected returns so as to arbitrage them away. In theory, investors should wish to diversify their portfolios and so should not entirely arbitrage away such a differential but rather should leave a risk premium, unless (1) they are risk neutral or (2) exchange risk is completely diversifiable, both extremely strong assumptions. But the magnitude of the risk premium is very much an open matter.

Cumby and Obstfeld $(1981,1984)$ and others have statistically rejected the hypothesis that the errors made by the interest differential in predicting exchange rate change are random. Given covered interest parity, the tests are equivalent to the (more numerous) tests of the hypothesis that the errors made by the forward discount in predicting exchange rate changes are random. In both cases, the standard finding is statistically significant serial correlation of prediction errors, and even a tendency for predictions to be incorrect as to the sign of exchange rate changes. Cumby and Obstfeld, and most others, have concluded from such evidence that uncovered interest parity fails. But as they recognize, the tests are in fact joint tests of uncovered interest parity and rational expectations. The evidence cannot distinguish which half of the joint null hypothesis is being rejected.

More information is needed to try to isolate the risk premiums out of the noisy prediction errors (out of the difference between the interest differential and the ex post changes in the exchange rate). The most natural source for such information is the theory of portfolio optimization on the part of investors. The theory says that the risk premium ought to be related to such factors as the degree of risk aversion, the supplies of various currencies that have to be held in investors' portfolios, the variance of the exchange rate in question, and the covariances with returns on other securities and with other investment opportunities. Econometric tests have looked for a systematic relationship between the prediction errors and the variables to which the theory says that the risk premium should be related, and have found no signs of such a relationship. ${ }^{19}$ As always, the statistical failure to reject the null hypothesis of a zero risk premium could be due to low power in the test. But there is a surprising, and more far-reaching, point that transcends the particular econometric technique used to estimate variances and covariances of 
rates of return. It is that conventional estimates of the degree of risk aversion imply that the risk premium must be very small.

It can be shown that if investors optimize with respect to the mean and variance of their wealth, they will allocate their portfolios according to the following equation:

$$
x_{t}=\alpha+[\rho \Omega]^{-1}\left(r p_{t}\right)
$$

where $x_{t}$ is the share of the portfolios allocated to foreign assets (or a vector of shares allocated to various foreign currencies); $\alpha$ is the minimum-variance portfolio, which is closely related to the share of consumption allocated to foreign goods (or a vector of such shares); $\rho$ is the coefficient of relative risk aversion; $\Omega$ is the variance (or variance-covariance matrix) of the return differential (that is, of the change in the exchange rate if one is looking at short-term financial assets with known nominal returns); and $r p_{t}$ is the risk premium on foreign assets (or vector), that is, the ex ante return differential or deviation from uncovered interest parity. ${ }^{20}$ Intuitively, an increase in the expected return on a particular asset will induce investors to shift a higher share of their portfolios into that asset; but the more important investors consider risk diversification (that is, the larger is $\rho$ or $\Omega$ ), the less will they shift their portfolios in response to a given change in expected returns.

The unconditional monthly variance of the relative return on dollars has been on the order of $.001 .^{21}$ The conditional variance, which is what should matter for investor behavior, must be less than or equal to the sample variance. Thus one may take .001 as an upper-bound estimate of $\Omega$. The coefficient of risk aversion, $\rho$, is thought to be in the neighborhood of two. ${ }^{22}$ Taking the product $[\rho \Omega]^{-1}$, it follows from equation 2.8 that asset demands are extraordinarily sensitive to the risk premium. If an increase in the supply of foreign assets $x_{t}$ equal to 1 percent of the portfolio is to be held willingly, it will have to drive up the risk premium $r p_{t}$ by .002 percent on a monthly basis, or a mere .024 percent per annum-just 2.4 basis points. It also follows that the magnitude of the risk premiums, not just the variability, is very small. ${ }^{23}$

It must be emphasized that the conclusion that international substitutability is very high, and thus the risk premium very small, depends entirely on the optimal portfolio argument. The hypothesis that investors diversify their portfolios optimally has not itself held up well to statistical tests. ${ }^{24}$

If one were to abandon the optimization hypothesis, one would be hard put to find other sources of information to help isolate the risk premium out of the noisy prediction errors made by the interest differential. About the only apparent alternative is the survey data of exchange rate expectations that made a brief appearance in table 2-1. These data do show a sizable gap between the interest differential and expected rate of depreciation, at least for 
the 1981-85 period of dollar appreciation. Unfortunately, the implied risk premium goes in precisely the opposite direction from that implied by the Cumby-Obstfeld test and other unbiasness tests on the interest differential or forward discount data. Those tests all imply that when the dollar sold at a discount, as it consistently did during the 1981-85 period, even though it has not depreciated ex post, dollar assets must be carrying a positive risk premium. The risk premium constitutes some positive fraction of the interest differential (100 percent of it, or more, in the case of tests that show predictions in the wrong directions). The natural explanation of why dollar assets might carry a positive risk premium in the mid-1980s is that, as a result of recent enormous federal budget deficits and current account deficits, the supply of dollar assets that the market must hold in its portfolio exceeds the share represented by the minimum-variance portfolio. But the survey data show that for the 1981-85 period, expected depreciation consistently exceeded the interest differential, that is, the risk premium on dollars was negative. They do not explain any positive fraction of the systematic component of the prediction errors.

I will return to the subject of the survey data subsequently. But for now, especially in light of the fact that the validity of these data as measures of expectations has yet to win widespread acceptance, I take the existing theoretical and empirical evidence as suggesting that international capital mobility is very high, in this second sense of high substitutability in investors' portfolios and a small risk premium. ${ }^{25}$

\section{Real Interest Parity}

So far I have concluded that capital is highly mobile between the United States and the other major countries both in the sense of (1) low transactions costs and capital controls, so that closed interest parity holds relatively well between U.S. securities and foreign securities (either denominated in dollars or covered on the forward market) and (2) low-risk premiums, so that uncovered interest parity holds relatively well also (though the evidence here is more widely disputed). How are such conclusions to be reconciled with the results of the Feldstein-Horioka tests already described?

Our third definition of perfect capital mobility is the one that Feldstein had in mind. It is phrased in terms of real interest rates, not nominal interest rates. It is, after all, the real interest rate on which saving and investment are thought to depend. The operational criterion is real interest parity:

$$
r_{\mathrm{US}}=r_{\mathrm{UK}}
$$

where $r_{\mathrm{US}} \equiv i_{\mathrm{US}}-\pi_{\mathrm{US}}^{e}, r_{\mathrm{UK}} \equiv i_{\mathrm{UK}}-\pi_{\mathrm{UK}}^{e}$, and $\pi_{\mathrm{US}}^{e}$ and $\pi_{\mathrm{UK}}^{e}$ are the countries' expected inflation rates. If infinitely elastic international flows 
were to tie the domestic real interest rate to the world real interest rate, and if the domestic country were small enough to take the world real interest rate as given, then there should be no crowding out: exogenous decreases in national saving should not drive up the domestic real interest rate and discourage domestic investment. In the Feldstein-Horioka regressions (with valid instrumental variables), the coefficients should be zero.

But, especially given the large-country and other endogeneity problems, a better econometric approach than saving-investment correlations is to test real interest parity directly. Such tests have been performed for the United States and major trading partners in the recent period by Mishkin (1984a, 1984b), Friedman and Schwartz (1982), von Furstenberg (1983), Cumby and Obstfeld (1984), and Cumby and Mishkin (1986). All find significant gaps between domestic and foreign real interest rates. Since real interest parity is the only definition of perfect capital mobility that could lead one to expect an absence of crowding out, its empirical failure automatically explains the finding of crowding out in the Feldstein-Horioka regressions. No arguments about econometric endogeneity are required. Furthermore, the general trend in the real interest rate results over time is the same as the general trend in the Feldstein-Horioka regressions. Mishkin (1984, pp. 1352, 1354), for example, found even more significant rejections of real interest parity for the floating rate period after $1973 /$ II than he did for his entire $1967 /$ II-1979/II sample period. This corresponds to the findings of Feldstein (1983) and Penati and Dooley (1984) that the crowding out coefficient did not decline as expected after 1973.

One need not search far for the source of failure of real interest parity. Even if the first two definitions of perfect capital mobility hold completely, so that uncovered interest parity holds,

$$
i-i^{*}=\Delta s^{e},
$$

it is necessary also to assume what is sometimes called ex ante relative purchasing power parity (PPP),

$$
\Delta s^{e}=\pi^{e}-\pi^{* e},
$$

if one is to derive real interest parity

$$
i-i^{*}=\pi^{e}-\pi^{* e} \text {. }
$$

Whether ex ante relative PPP (also describable as "random walk expectations regarding the real exchange rate") holds is a question regarding the degree of integration of international goods markets (which is thought to be low), not the degree of integration of international financial markets. Here it is impor- 
tant to note that international portfolio investors have reason to arbitrage away gaps in countries' nominal rates of return when expressed in a common numeraire; but they have no reason to arbitrage away a gap between the domestic rate of return expressed in terms of domestic goods and the foreign rate of return expressed in terms of foreign goods. Perhaps the central message of this chapter is that, although Feldstein and Horioka are correct about the existence of crowding out, econometric endogeneity problems notwithstanding, they are wrong to offer this conclusion as evidence of imperfect capital mobility. ${ }^{26}$

It might be protested that my first two definitions of capital mobility refer only to nominal assets-bonds and, especially, shorter-term bills or deposits-and that a perfectly good third definition would refer to real assets-equities and direct investment. But the same argument applies. In the absence of significant barriers to mobility or substitutability (including risk), an international investor should equate the expected rate of return on equities or real investment in one country to that in another evaluated in a common numeraire, not each evaluated in terms of local goods prices. If the real return on a country's equities were equal to the real return on its bonds, with each evaluated in terms of local goods prices, and if real interest parity held, then the real returns on equities would be internationally equalized as well. But given the failure of real interest parity, neither foreign direct investment nor any other known force will equalize real returns on capital. Thus equating internationally rates of return on financial assets of any sort will not be sufficient to equate real interest rates; ex ante relative purchasing power parity is needed as well.

\section{Ex Ante Purchasing Power Parity}

Not long ago, purchasing power parity was widely accepted. It was argued on a priori grounds that the law of one price should be enforced at least for traded goods: If automobiles were selling at a lower price in Germany than in the United States, international arbitrageurs should buy them in Germany and sell them in the United States, raising the price in one country or lowering it in the other until equality was restored. If PPP were to hold in level form, then it would also hold in expected rate of change form (equation 2.11); goods markets would pose no obstacles to real interest parity.

The empirical evidence against PPP in level form is overwhelming. The enormous real appreciation of the dollar in the 1980s has now convinced the remaining doubters, but abundant statistical evidence was there all along. For example, Krugman (1978, p. 406) computed for the floating rate period July 1973-December 1976 standard deviations of the (logarithmic) real exchange rate equal to 6.0 percent for the pound/dollar rate and 8.4 percent for the mark/dollar rate. He also computed serial correlation coefficients for 
Table 2-7

Purchasing Power Parity between the United States and the United Kingdom, 1869-1984

\begin{tabular}{|c|c|c|c|c|}
\hline & $1973-1984$ & $1945-1972$ & $1945-1984$ & $1869-1984$ \\
\hline Mean absolute deviation & .121 & .075 & .106 & .093 \\
\hline Standard deviation & .154 & .092 & .146 & .122 \\
\hline Time trend & $\begin{array}{l}-.001^{*} \\
(.0003)\end{array}$ & $\begin{array}{l}.006^{*} \\
(.002)\end{array}$ & $\begin{array}{r}-.0004 \\
(.0022)\end{array}$ & $\begin{array}{l}.009 \\
(.013)\end{array}$ \\
\hline $\begin{array}{l}\text { Autoregression } \\
\text { of deviations from mean }\end{array}$ & $\begin{array}{l}.720^{4} \\
(.248)\end{array}$ & $\begin{array}{l}.706^{*} \\
(.132)\end{array}$ & $\begin{array}{l}.829^{*} \\
(.090)\end{array}$ & $\begin{array}{l}.860^{*} \\
(.048)\end{array}$ \\
\hline of deviations from trend & $\begin{array}{l}.734^{*} \\
(.277)\end{array}$ & $\begin{array}{l}.710^{*} \\
(.133)\end{array}$ & $\begin{array}{l}.750^{*} \\
(.106)\end{array}$ & $\begin{array}{l}.846^{*} \\
(.050)\end{array}$ \\
\hline \multicolumn{5}{|l|}{$\begin{array}{l}\text { Regression against nominal } \\
\text { exchange rate }\end{array}$} \\
\hline coefficient $t^{\mathrm{a}}$ & $\begin{array}{l}1.051^{*} \\
(.083)\end{array}$ & $\begin{array}{l}1.057^{*} \\
(.073)\end{array}$ & $\begin{array}{l}1.005^{*} \\
(.069)\end{array}$ & $\begin{array}{l}.763^{*} \\
(.055)\end{array}$ \\
\hline autocorrelation coefficient & .874 & .970 & .984 & .991 \\
\hline
\end{tabular}

Note: Standard errors are reported in parentheses.

* Significant at the 95 percent level.

${ }^{a}$ With constant term and Cochrane-Orcutt correction for autocorrelation.

PPP deviations of .897 and .854 , respectively, on a monthly basis, equal to .271 and .150 on an annual basis. The serial correlation coefficient is of interest because it is equal to one minus the speed of adjustment to PPP. It may be best not to rely exclusively on the standard deviation of the real exchange rate as a summary statistic for the degree of integration of goods markets because it in part reflects the magnitude of monetary disturbances during the period. ${ }^{27}$

Table 2-7 shows updated annual statistics on the real exchange rate between the United States and Great Britain. During the floating rate period 1973-84, though there is no significant time trend, there is a large standard deviation of 15.4 percent. The serial correlation in the deviations from PPP is estimated at .720 , with a standard error of .248 . (The equation estimated is $\left[e r_{t+1}-\overline{e r}_{t+1}\right]=A R\left[e r_{t}-\overline{e r}_{t}\right]$, where $e r$ is the real exchange rate and $\overline{e r}$ is the long-run equilibrium level, alternatively estimated as the sample mean or a time trend, and $A R$ is the autoregressive coefficient.) This means that the estimated speed of adjustment to PPP is .280 per year and that one can easily reject the hypothesis of instantaneous adjustment.

From the ashes of absolute PPP, a phoenix has risen. In response to findings such as those reported here, some authors have swung from one extreme, the proposition that the tendency of the real exchange rate to return to a constant is complete and instantaneous, to the opposite extreme that 
there is no such tendency at all. The hypothesis that the real exchange rate follows a random walk is just as good as the hypothesis of absolute PPP for implying ex ante relative PPP. But there is even less of an a priori case why PPP should hold in rate-of-change form than in the level form.

Roll (1979) has claimed that the random walk model of the real exchange rate has a basis in efficient markets theory. His argument is apparently that if the expected inflation rate is lower in the United States than in Germany, allowing for expected exchange rate changes, then an arbitrageur can contract to buy automobiles in the United States and ship them to Germany and expect to sell them there at a higher price; such profitable arbitrage would then eliminate the opportunity to begin with, enforcing PPP in expected rateof-change form. If this arbitrage is intended to be different from the old arbitrage in level form which has been empirically rejected, and Roll clearly intends it to be different, then it is a remarkable strategy to recommend to international traders. Measures of expected real depreciation of the dollar as of 1985 showed a short-term depreciation rate of about 1.0 percent per annum. As of 1985, the level of BMW prices was said to be almost twice as high in the United States as in Germany, as a result of the five-year appreciation of the dollar against the mark. Yet Roll's apparent strategy tells people to buy BMWs in the United States and ship them to Germany because in the three months it takes to complete the shipment their relative prices will have increased 0.25 percent in expected value! The near-50-percent loss would seem to outweigh the 0.25 -percent gain.

Even though ex ante relative PPP has little basis in theory, it does appear to have some empirical support. Typically, the estimated speeds of adjustment during the floating rate period, .27 or .28 on an annual basis in table 2-7 (1973-84), while not so low as to be implausible as point estimates, are nevertheless so low that one statistically cannot reject the hypothesis that they are zero. In other words, one cannot reject the hypothesis that the autoregression coefficient is 1.0 .

A 95 -percent confidence interval on the autoregressive coefficient covers the range 0.17 to 1.27 (in the no-trend case). If the null hypothesis is an autoregression coefficient of 1.0 , one cannot legitimately use the standard $t$-test derived from a regression where the right-hand variable is the level of the real exchange rate, because under the null hypothesis its variance is infinite. (This does not invalidate the $t$-test just reported of the null hypothesis that the tendency to return to PPP was 100 percent, that is, $A R=0$ ). There are a number of ways of dealing with this nonstationarity problem. Here one simply applies the corrected Dickey-Fuller cumulative probability distribution for this problem. The $t$-ratio to test an autoregressive coefficient of 1.0 is 1.13 , which falls far short of the Dickey-Fuller 95-percent significance level, 3.00.

This failure to reject a random walk in the real exchange rate is the same result found by Roll (1979), Frenkel (1981, p. 699), Darby (1981), and 
Mishkin (1984, pp. 1351-53). Most of these studies used monthly data. On the one hand, the more abundant data reduces the standard error of the estimate but, on the other hand, one is no longer testing whether $A R=.28$ is different from 1.0, but rather whether, say, $A R 1 / 12=.90$ is different from 1.0 , so that it may not be much easier to reject. Another problem is that one cannot be sure that the nature of the true autoregressive process is firstorder on a monthly (or continuous-time) basis; the typical finding is that computations on monthly data imply a somewhat more rapid speed of adjustment when annualized than do computations performed directly on annual data, suggesting that the process may not be exactly first order. In any case, the monthly data in the studies cited were generally not powerful enough to reject the random walk. ${ }^{28}$

A more promising alternative is to choose a longer time sample. Table 2-7 also reports statistics for the entire postwar period 1945-84. PPP held slightly better during the Bretton Woods years than it did after 1973, as measured either by the mean absolute deviation and standard deviation of the real exchange rate, or by the ability to reject the hypothesis of zero autocorrelation. But, despite the longer time sample, one is still unable to reject the random walk. The 95-percent confidence interval runs from .65 to 1.01 , and the $t$-ratio of 1.9 falls short of the Dickey-Fuller 95 -percent significance level of 2.93 .

The last column of table $2-7$ presents an entire 116 years of U.S.-U.K. data. With this long a time sample, the standard error is reduced considerably. The rejection of no serial correlation in the real exchange rate is even stronger than in the shorter time samples. More important, one is finally able to detect a significant tendency for the real exchange rate to regress to PPP, at a rate of 14 percent a year. The confidence interval for $A R$ runs from .77 to .95 , safely less than unity, and the $t$-ratio of 2.92 exceeds the Dickey-Fuller significance level of 2.89 .

The last row of the table reports regressions of the real exchange rate against the nominal exchange rate. The coefficient is highly significant for the 1869-1984 period. The figures suggest that changes in the nominal exchange rate (for example, due to devaluations under fixed exchange rates or monetary disturbances under floating exchange rates) cause transitory changes in the real exchange rate because goods prices are sticky. Such results specifically rule out the possibility, which is suggested occasionally in the literature, that apparent deviations from PPP might be attributed to random measurement errors in the price data.

In this chapter, my motivation for looking at PPP is to obtain insight into the expected rate of real depreciation, because that is the variable that separates the real interest differential from the risk premium. In rejecting the random walk description of the real exchange rate, one has rejected the claim that the rationally expected rate of real depreciation is zero. 
The rationally expected rate of real depreciation estimated from a specific time series process is in any case not necessarily the same as the actual expectation of real depreciation held by investors. People could be either less sophisticated or more sophisticated than the autoregressive model.

Table 2-8 uses the Economist and American Express survey data on expectations of exchange rate and price level changes to compute a direct measure of expected real depreciation for the dollar against five individual currencies, and regress it against a measure of current real "overvaluation." Overvaluation is the difference between the current exchange rate and a longrun equilibrium rate calculated by PPP, using as the base the average of the period 1973-80. The equilibrium measure differs from a constant in that it evolves over time at the rate of the inflation differential, and in that when the regression period is confined to the period $1981-84$, as is necessarily the case for the Economist data set, it shows a large real overvaluation throughout. According to the results in table 2-8, investors show a statistically significant expectation that the real exchange rate will regress back toward PPP. ${ }^{29}$ The constant term is also statistically significant. ${ }^{30}$

One can take point estimates from table 2-7 to illustrate what a typical magnitude might be for the rationally expected rate of real depreciation even in the absence of any expected changes in the long-run equilibrium terms of trade. For the 1869-1984 period a 1-percent deviation from PPP, say, an "overvaluation" of the currency, implies a rationally expected rate of subsequent real depreciation equal to 0.14 percent per year. Since the mean absolute deviation from PPP is 9.3 percent, the mean absolute value of the rationally expected rate of real depreciation is $0.14 \times 9.3=1.3$ percent. In the post-1973 period of larger exchange rate fluctuations, the magnitude of expected real depreciation is larger. The most dramatic case is 1984 or 1985 , when calculations of real overvaluation of the dollar (relative to PPP) on the order of 30 percent imply that the rationally expected rate of future real depreciation back toward PPP is large enough to explain all of the real interest differential, calculated in the various ways shown in table $2-1 .{ }^{31}$

A more precise decomposition of the real interest differential into a risk premium and expected real depreciation, based on the assumption of rational expectations and the use of ex post data, is difficult. The reason is that the difference between the expected exchange rate change and the ex post exchange rate change, even though random if expectations are rational, is so large as to reduce greatly the precision of any estimates, as Mishkin (1984a) notes. Indeed it was for this reason that Mishkin was unable to reject the hypotheses of a zero risk premium or of zero expected real depreciation considered individually, even though he could easily reject the joint null hypothesis in a test of real interest parity, where the exchange rate expectation errors do not interfere.

It should be recalled from the subsection Uncovered Interest Parity that, 
International Capital Mobility and Crowding-out -59

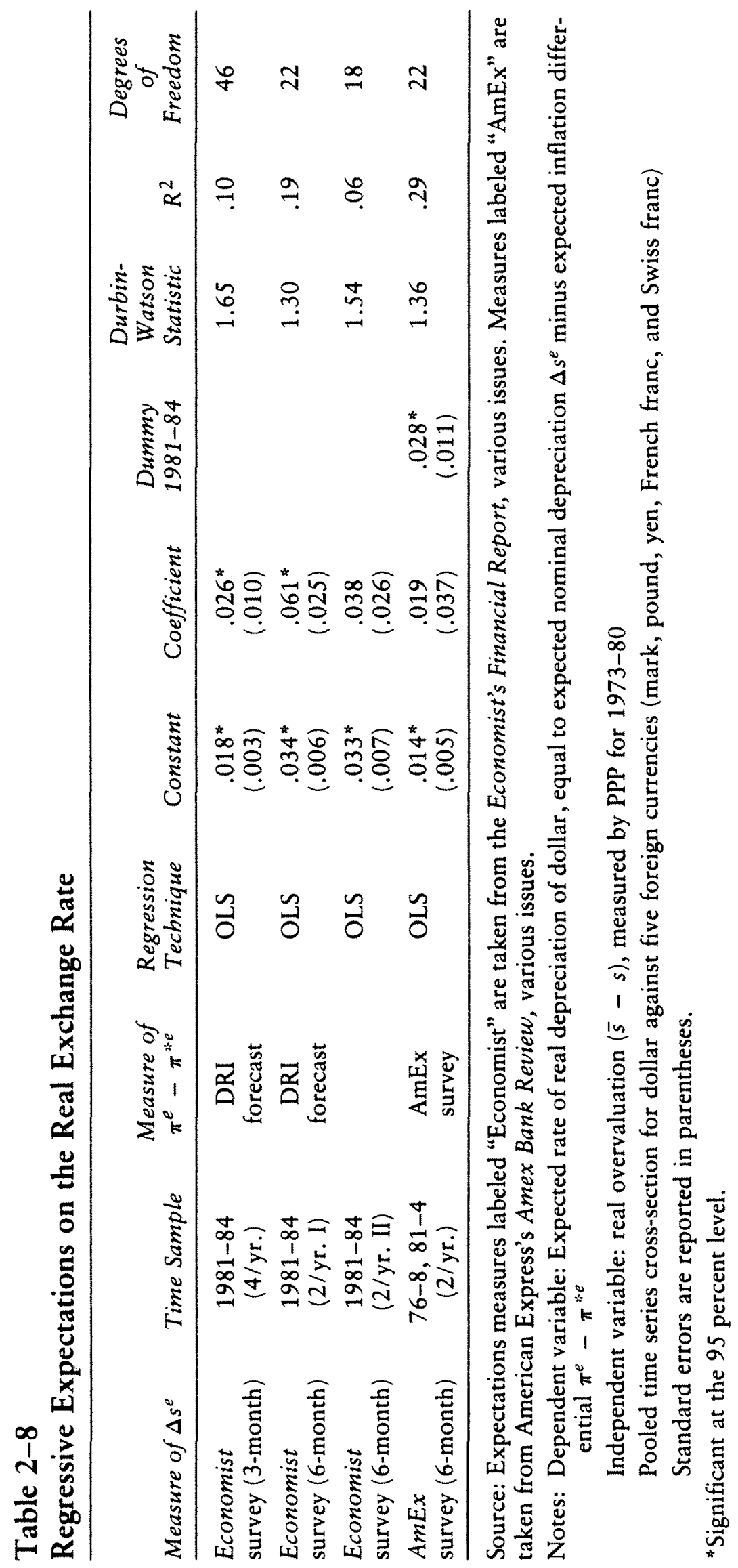


on the one hand, the standard tests of unbiasness in the forward discount or interest differential say that the rationally expected rate of depreciation is significantly less than that implied by the interest differential, and, on the other hand, that economists' notions of a long-run equilibrium for the dollar, as embodied for example in the Economist and American Express survey data, imply that the expected rate of depreciation as of 1985 was considerably greater. One cannot prove that expected real depreciation explains 100 percent of the real interest differential, no less and no more. But the calculations of this section are intended to show that plausible magnitudes for the former correspond to plausible magnitudes for the latter, and that deviations from the assumption of perfect capital mobility in the senses of the first two definitions raised earlier in the section Three Interest Parity Conditions as Definitions of Capital Mobility are not needed to explain deviations from real interest parity.

\section{Conclusion}

Regressions of the investment rate against the national saving rate give results for U.S. time series similar to those obtained by Feldstein-Horioka and others for cross-sectional data: a point estimate on the order of .8 , significantly different from zero and insignificantly different from 1.0. Econometric problems abound, but cyclically adjusting the saving and investment numbers, using instrumental variables, or working in terms of deviations from world levels does little to reduce the coefficient estimate. The estimate has, if anything, been moving closer to 1.0 in the postwar period. It seems that international capital mobility does not fully prevent exogenous changes in the government budget or in private saving from crowding out domestic investment.

This chapter has argued that neither imperfect capital mobility nor econometric problems are needed to explain the crowding out estimates. "Perfect capital mobility" has multiple definitions: (1) closed interest parity, requiring insignificant barriers such as transactions costs and capital controls; (2) uncovered interest parity, requiring also small exchange risk premiums; and (3) real interest parity, requiring also ex ante relative purchasing power parity. Each criterion can be tested directly. Closed interest parity is observed to hold well among eight of the major industrial countries. Uncovered interest parity is more difficult to test, because investors' exchange rate expectations are not directly observable; nevertheless some theoretical considerations and some evidence from survey data both contradict the view that a large positive component of the interest differential (or forward discount) on the dollar constitutes a risk premium. Thus the first two criteria, the ones that are most properly associated with the degree of integration of financial mar- 
kets, do seem to hold to within relatively small margins. Real interest parity, the only condition that might lead one to expect an absence of crowding out, is also the condition that clearly fails empirically. This is not surprising, since purchasing power parity is well known to fail empirically, while the argument that ex ante relative PPP could hold nevertheless is extremely weak on both theoretical grounds and empirical grounds. When 116 years of data on the U.S.-U.K. real exchange rate are used, it is possible to reject the random walk characterization and to find a statistically significant speed of adjustment to PPP.

Thus expected real depreciation is an important variable. It seems possible to attribute all of, for example, the 3.0-percent U.S. real interest differential (as of 1985) to expected real depreciation, rather than to a risk premium. This implies that it is possible to attribute the existence of crowding out in an open economy to imperfect integration of goods markets, rather than necessarily to imperfect integration of asset markets as has been suggested in the past.

\section{Notes}

1. The share averages .0379 for $1929-44, .0478$ for $1945-73$ and .0897 for 1974-84. Figures are from the International Monetary Fund's data base. These longrun trends in U.S. trade are examined in Lipsey (1984). See also Cooper (this volume).

2. There are a number of ways that these strong results can be watered down. One way particularly relevant for the United States is the large-country point: to the extent that a fiscal expansion succeeds in driving up the worldwide interest rate, it will have succeeded in raising income and crowding out investment (both effects holding abroad as well as domestically).

3. The decline in saving net of the capital consumption allowance has been even more pronounced. See table 4 in Friedman (1985).

4. The average investment rate in the 1981-84 period encompasses a fall in the first two recession years and a rise in the subsequent two recovery years; investment, like saving, is of course highly procyclical. There has been talk, especially in 1984, of an investment boom. But Bosworth (1985) suggests that the favorable effect that the 1981 corporate tax law changes had on the cost of capital to firms was more than offset by the unfavorable effect of the increase in real interest rates, and that any appearances of an investment boom in 1983-85 were due to the recovery and the existence of new computer technology. See also Friedman (1985). In any case, it must be that the increase in real interest rates has acted to depress investment relative to what it otherwise would be.

5. Two other papers that discuss both the Feldstein-Horioka notion of international capital mobility and the more conventional definitions are Boothe et al. (1985) and Obstfeld (1985).

6. Other cross-sectional studies include Fieleke (1982), Feldstein (1983), Penati and Dooley (1984), Murphy (1984), Caprio and Howard (1984), and Summers 
(1985). However, Obstfeld (1985) used time series data, as did Sachs (1981) but with the inclusion of a GNP gap variable.

7. Tobin (1983), Murphy (1984), and Obstfeld (1985) criticized Feldstein and Horioka on these grounds.

8. The "policy reaction" argument has been made by Fieleke (1982), Tobin (1983), Westphal (1983), Summers (1985), and Caprio and Howard (1984).

9. Many of the critiques ignore the fact that the original Feldstein and Horioka paper used instrumental variables. (The four instruments were the ratio of retirees over 65 to the working age population, the ratio of younger dependents to the same population, the labor force participation rate of older men, and the benefit/earning "replacement ratio" under social security.)

10. For example, Caprio and Howard (1984), Obstfeld (1985), and Summers (1985).

11. All saving and investment numbers used in this chapter are gross rather than net. Harberger (1980) argued that gross numbers bias upward the Feldstein-Horioka (1980) coefficients estimates, but Feldstein (1983) showed that the same results held with net numbers.

12. We tried splitting the sample of decade data at 1919 to try to see how U.S. capital mobility changed over time, but as one would expect from the very small number of observations, the estimates were so imprecise as to be worthless $(-2.69$ with a standard error of 2.0 , and .75 with a standard error of .38 , respectively). Reliable yearly data are not available from before World War I, aside from the problem of cyclical endogeneity.

13. David and Scadding (1974) argue that "Denison's Law," the stability of private saving as a fraction of GNP in the postwar period, applies also to preceding U.S. history, despite shifts from personal saving to durables expenditure and corporate saving. (Their period is 1898-1964.) But as they point out, the stability of private saving in the face of a rising and fluctuating government deficit precludes the stability of aggregate national saving that would be implied by the theories mentioned early in the first section of this chapter.

14. The standard error of the coefficient is .172 , the $R^{2}$ is .59 , and the DurbinWatson statistic is 1.66 . The numbers are not cyclically adjusted, but to the extent that business cycles are internationally synchronized (as they should be under conditions of high capital mobility), cyclical effects should be less important in the differential rates.

15. This is the definition of perfect capital mobility that I argued is the most sensible, to distinguish it from perfect substitutability (the second definition, considered shortly) in Frankel (1983); supporting citations appear there.

16. Dooley and Isard (1980, p. 382-83), Argy (1982, pp. 35, 38, 43, 76-79), and Baumgartner (1977) give the history of German capital controls in the 1970s.

17. Claassen and Wyplosz (1982) and Frankel (1982b) also document the case for France.

18. The sign of the deviation switched, from a mean of -1.84 in the first period to +0.26 in the second period. This is evidence that, although the earlier controls acted to prevent capital inflow into Japan (otherwise investors would not have settled for the Euroyen interest rate in London when a higher return was available in Tokyo), those controls that remained after April 1979 acted more to prevent capital outflow. 
(Otherwise investors would not have settled for the interest rate in Tokyo if a higher Euroyen rate were freely available in London.) It is ironic that the United States in 1983-84 pushed for further Japanese liberalization with the express goal of strengthening the yen, when liberalization could be expected to result in greater capital outflow in response to higher interest rates in the United States, and thus to weaken the yen. The calculations cited here appear in Frankel (1984, pp. 21-24); the numbers are originally from Morgan Guaranty. See also Otani and Tiwari (1981) and Otani (1983).

19. For example, Frankel (1982a), which also gives further references.

20. Derivations appear in Dornbusch (1983) for the case of two assets and stochastic goods prices, in Krugman (1981) for the case of two assets and nonstochastic goods prices, in Frankel and Engel (1984) for the case of $n$ assets and stochastic goods prices, and in Frankel (1982a) for the case of $n$ assets and nonstochastic goods prices.

21. The period is August 1973-August 1980; Frankel (1985). The calculations assume a constant (conditional) variance.

22. Friend and Blume (1975) estimate $\rho$ to be in the neighborhood of two in the context of investors' portfolio behavior. Stern (1977) provides a survey of estimates in other contexts, most also in the neighborhood of two.

23. Krugman (1981) and Frankel (1985) show that if $\rho \Omega$ is small, then both the level of the risk premium and changes are small. More generally, past tests of biasness in the forward discount or interest differential have not found unconditional bias; those who have argued for the existence of a large risk premium have always specified that it be time varying, so as to fluctuate between positive and negative (for example, Hansen and Hodrick (1983)).

24. Frankel and Engel (1984) reject the international optimization hypothesis in a mean-variance framework. Hodrick and Srivistava (1984) do so in a more general intertemporal framework.

25. Frankel and Froot (1985) introduce the survey data, test alternative specifications for the expectations formation process, and test the rational expectations hypothesis. Froot (1985) further investigates whether the standard findings of biasness in the forward discount can be attributed to a risk premium, and allows for measurement error in the survey data.

26. Feldstein and Horioka (1980) and Feldstein (1983) explicitly refer to barriers to integration of financial markets. Among the many subsequent authors who seem automatically to accept the conceptual jump from crowding out to imperfect financial market integration are Tobin (1983), Murphy (1984), Caprio and Howard (1984), and Boothe et al. (1985). Obstfeld (1985) and Summers (1985) note the relevance of changes in relative goods prices, though they phrase the distinction differently both from each other and from me here.

27. For example, Krugman found that the standard deviation for the real mark/ dollar exchange rate during the German hyperinflation, February 1920-December 1923 , was much larger ( 20.8 percent) than during the 1970 s, even though the serial correlation was no higher (.765).

28. Cumby and Obstfeld (1984, p. 146) used a $Q$-statistic to test for higher order serial correlation in monthly real exchange rate changes and found none. However, they also found that expected inflation differentials are unrelated to expected exchange rate changes, rejecting the random walk characterization of the real exchange rate. 
29. Because the data sample is pooled time series cross-section, there is certain to be correlation of the error term across different currencies. The system should be estimated by Seemingly Unrelated Regressions, as is done in Frankel and Froot (1985).

30. The American Express data set covers a longer time period, 1976-84, but fewer observations. The addition of a dummy variable for the strong-dollar period after 1980 eliminates the significance of the regressive coefficient. The results without the dummy variable are significant, but not reported in table 2-8.

31. The 1984 Economic Report of the President, chap. 2, found that the expected future real depreciation implicit in the real interest differential roughly coincided with the "real overvaluation" implied by the PPP. But any such calculations are very sensitive to the term of maturity chosen.

\section{References}

Aliber, Robert. "The Interest Rate Parity Theorem: A Reinterpretation," Journal of Political Economy 81 (1973), pp. 1451-59.

- "The Integration of National Financial Markets: A Review of Theory and Findings," Weltwirtschaftliches Archiv 114, no. 3 (1978), pp. 448-79.

Argy, Victor. Exchange-Rate Management in Theory and Practice, Princeton Studies in International Finance 50. Princeton, N.J.: International Finance Section, Princeton University (October 1982).

Baumgartner, Ulrich. "Capital Controls in Three Central European Countries." International Monetary Fund DM/77/12 (February 1977).

Boothe, P., K. Clinton, A. Côté, and D. Longworth. International Asset Substitutability: Theory and Evidence for Canada. Ottawa: Bank of Canada (February 1985).

Bosworth, Barry. "Taxes and the Investment Recovery." Brookings Papers on Economic Activity (1985), pp. 1-45.

Caprio, Gerard, and David Howard. "Domestic Saving, Current Accounts, and International Capital Mobility," International Finance Discussion Papers no. 244. Washington, D.C.: Federal Reserve Board (June 1984).

Claassen, Emil, and Charles Wyplosz. "Capital Controls: Some Principles and the French Experience." Annales de l'INSEE 47-48 (June-December 1982), pp. 237-67.

Cooper, Richard. "The United States as an Open Economy," in this volume.

Cumby, Robert, and Frederick Mishkin. "The International Linkage of Real Interest Rates: The European-U.S. Connection," Journal of International Money and Finance 5 (1986), pp. 5-24.

Cumby, Robert, and Maurice Obstfeld, "A Note on Exchange Rate Expectations and Nominal Interest Differentials: A Test of the Fisher Hypothesis," Journal of Finance 36 (1981), pp. 697-704.

_- "International Interest Rate and Price Level Linkages under Flexible Exchange Rates: A Review of Recent Evidence" in J. Bilson and R. Marston, eds., Exchange Rate Theory and Practice. Chicago: University of Chicago Press (1984).

David, Paul, and John Scadding. "Private Savings: Ultrarationality, Aggregation, and 'Denison's Law," Journal of Political Economy (March-April 1974), pp. $225-49$. 
Dooley, Michael, and Peter Isard. "Capital Controls, Political Risk and Deviations from Interest-Rate Parity," Journal of Political Economy 88, no. 2 (April 1980), pp. 370-84.

Dornbusch, Rudiger. "Exchange Rate Risk and the Macroeconomics of Exchange Rate Determination" in R. Hawkins, R. Levich, and C. Wihlborg, eds., The Internationalization of Financial Market and National Economic Policy. Greenwich, Conn.: JAI Press (1983), pp. 3-27.

Fase, M.M.G., "The Interdependence of Short-Term Interest Rates in the Major Financial Centers of the World: Some Evidence for 1961-1972," Kyklos 29 (1976), pp. 63-96.

Feldstein, Martin. "Domestic Saving and International Capital Movements in the Long Run and the Short Run," European Economic Review 21 (1983), pp. 129-151.

Feldstein, Martin, and Charles Horioka. "Domestic Saving and International Capital Flows," Economic Journal 90 (1980), pp. 314-29.

Fieleke, Norman. "National Saving and International Investment" in Saving and Government Policy, Conference series no. 25. Federal Reserve Bank of Boston (1982).

Frankel, Jeffrey. "In Search of the Exchange Risk Premium: A Six-Currency Test Assuming Mean-Variance Optimization," Journal of International Money and Finance 1 (1982), pp. 255-74.

- "On the Franc," Annales de l'INSEE 47-48 (July-December 1982), pp. $185-221$.

- "Monetary and Portfolio-Balance Models of Exchange Rate Determination" in J. Bhandari, ed., Economic Interdependence and Flexible Exchange Rates. Cambridge, Mass.: MIT Press (1983).

- The Yen/Dollar Agreement: Liberalizing Japanese Capital Markets, Policy Analyses in International Economics no. 9. Washington, D.C.: Institute for International Economics (1984).

- "The Implications of Mean-Variance Optimization for Four Questions in International Macroeconomics," Journal of International Money and Finance, forthcoming.

Frankel, Jeffrey, and Charles Engel. "Do Asset-Demand Functions Optimize over the Mean and Variance of Real Returns? A Six-Currency Test," Journal of International Economics 17 (1984), pp. 309-23.

Frankel, Jeffrey, and Kenneth Froot. "Using Survey Data to Test Some Standard Propositions Regarding Exchange Rate Expectations," National Bureau of Economic Research Working Paper (August 1985).

Frenkel, Jacob. "The Collapse of Purchasing Power Parity during the 1970s," European Economic Review 16 (February 1981), pp. 145-65.

- "Flexible Exchange Rates, Prices, and the Role of 'News': Lessons from the 1970s," Journal of Political Economy 89, no. 4 (August 1981), pp. 665-705.

Frenkel, Jacob, and Richard Levich. "Covered Interest Arbitrage: Unexploited Profits?" Journal of Political Economy 83, no. 2 (April 1975), pp. 325-38.

-. "Transaction Costs and Interest Arbitrage: Tranquil versus Turbulent Periods," Journal of Political Economy 85, no. 6 (December 1977), pp. 1209-26.

Friedman, Benjamin. "Implications of the U.S. Net Capital Inflow" in this volume.

Friedman, Milton, and Anna Schwartz. Money, Interest Rates, and Prices in the 
United States and United Kingdom: 1867-1975.Chicago: University of Chicago Press (1982).

Friend, Irwin, and Marshall Blume. "The Demand for Risky Assets," American Economic Review 65 (December 1975), pp. 900-22.

Froot, Kenneth. "Exchange Rate Survey Data: The Roles of Expectational Errors, the Risk Premium and Measurement Error." Department of Economics, University of California, Berkeley (September 1985).

Giavazzi, Francesco, and Marco Pagano. "Capital Controls and the European Monetary System" in Capital Controls and Foreign Exchange Legislation, Occasional Paper. Milano: Euromobiliare (June 1985).

Hansen, Lars, and Robert Hodrick. "Risk-Averse Speculation in the Forward Foreign Exchange Market: An Econometric Analysis of Linear Models" in J. Frenkel, ed., Exchange Rates and International Macroeconomics. Chicago: University of Chicago Press (1983).

Harberger, Arnold. "Vignettes on the World Capital Market," American Economic Review 70 (1980), pp. 331-37.

Hartman, David. "The International Financial Market and U.S. Interest Rates," Journal of International Money and Finance 3 (April 1984), pp. 91-103.

Hodrick, Robert, and Sanjay Srivistava. "An Investigation of Risk and Return in Forward Foreign Exchange," Journal of International Money and Finance 3 (1984), pp. 5-24.

Krugman, Paul. "Purchasing Power Parity and Exchange Rates: Another Look at the Evidence," Journal of International Economics 8, no. 3 (1978), pp. 397-407.

-. "Consumption Preferences, Asset Demands and Distribution Effects in International Financial Markets," National Bureau of Economic Research, Working Paper no. 651 (March 1981).

Lipsey, Robert. "Recent Trends in U.S. Trade and Investment" in N. Miyawaki, ed., Problems of Advanced Economics, Proceedings of the Third Conference on New Problems of Advanced Societies, Tokyo, November 1982. Heidelberg: SpringerVerlag (1984), pp. 58-74.

Mishkin, Frederic. "Are Real Interest Rates Equal across Countries? An Empirical Investigation of International Parity Conditions," Journal of Finance 39 (1984a), pp. 1345-58.

- "The Real Interest Rate: A Multi-Country Empirical Study," Canadian Journal of Economics 17, no. 2 (May 1984b), pp. 283-311.

Murphy, Robert. "Capital Mobility and the Relationship between Saving and Investment in OECD Countries," Journal of International Money and Finance 3 (1984), pp. 327-42.

Obstfeld, Maurice. "Capital Mobility in the World Economy: Theory and Measurement," paper presented at the Carnegie-Rochester Public Policy Conference (1985).

Otani, Ichiro. "Exchange Rate Instability and Capital Controls: The Japanese Experiense 1978-81" in D. Bigman and T. Taya, eds., Exchange Rate and Trade Instability: Causes, Consequences and Remedies. Cambridge, Mass.: Ballinger (1983).

Otani, Ichiro, and Siddarih Tiwari. "Capital Controls and Interest Parity: The Japanese Experience 1978-81, IMF Staff Papers (December 1981). 
Penati, Alessandro, and Michael Dooley, "Current Account Imbalances and Capital Formation in Industrial Countries, 1949-1981." IMF Staff Papers 31 (1984), pp. 1-24.

Ransom, Roger, and Richard Sutch. "Domestic Saving as an Active Constraint on Capital Formation in the American Economy, 1839-1928: A Provisional Theory." University of California Project on the History of Saving, Working Paper no. 1, University of California, Berkeley (1983).

Roll, Richard. "Violations of Purchasing Power Parity and Their Implications for Efficient International Commodity Markets" in M. Sarnat and G. Szego, eds., International Finance and Trade, vol. 1. Cambridge, Mass.: Ballinger (1979).

Sachs, Jeffrey. "The Current Account and Macroeconomic Adjustment in the 1970s" in Brookings Papers on Economic Activity, vol. 12. Washington, D.C.: Brookings Institution (1981), pp. 201-68.

-. "Aspects of the Current Account Behavior of OECD Economies" in E. Claassen and P. Salin, eds., Recent Issues in the Theory of Flexible Exchange Rates. Amsterdam, North-Holland (1983).

Stern, Nicholas. "The Marginal Valuation of Income" in M.J. Artis and A.R. Nobay, eds., Studies in Modern Economic Analysis. Oxford, England: Basil Blackwell (1977), pp. 145-76.

Summers, Lawrence. "Tax Policy and International Competitiveness," National Bureau of Economic Research Working Paper (March 1985).

Tobin, James. "Comments on Domestic Saving and International Capital Movements in the Long Run and the Short Run," European Economic Review 21 (1983), pp. 153-56.

von Furstenberg, George. "Changes in U.S. Interest Rates and Their Effects on European Interest and Exchange Rates" in D. Bigman and T. Taya, eds., Exchange Rate and Trade Instability: Causes, Consequences and Remedies. Cambridge, Mass.: Ballinger (1983).

Westphal, Uwe. "Comments on Domestic Saving and International Capital Movements in the Long Run and the Short Run," European Economic Review 21 (1983), pp. 157-59. 